\title{
Idea twórczości i figura artysty w singeries Davida Teniersa Młodszego, Antoine'a Watteau i Jeana Chardina
}

DOI: https://doi.org/10.21697/an.7932

JOANNA STRZEMECKA

WARSZAWA

Przedstawienia antropomorficznych zwierząt zachowujących się jak ludzie, często ubranych w ludzkie stroje są używane od średniowiecza przede wszystkim w charakterz satyrycznym. Wyja kowe mo w takim sposobie obrazowa ta malpa.ze wz gedu swoje niew yodne podobieństwo doczlowieka postrzegana była jako jego karykatura, a zdolności do odtwarzania gestów i mimiki uczyniły z niej znakomite narzędzie ośmieszania ludzi. Artyści wykorzystywali te cechy zwierzęcia w scenach zwanych singerie (z fr. matpiarnia, matpiarstwo) - przedstawiających małpy parodiujące ludzkie zachowania. Temat ten, choć sięga średniowiecza, w samodzielnej formie pojawił się w ostatniej ćwierci XVI w., żeby w kolejnym stuleciu stać się popularnym gatunkiem flamandzkiego malarstwa rodzajowego i powszechnie stosowanym motywem wego i powszechnie stosowanym motywem w XVIII-wiecznej Francji. Te humorystyczne przedstawienia służyły głównie ukazaniu człowieka i jego działań w krzywym zwier-
ciadle, w myśl słów: simia quam similis turpissima bestia nobis.

Były to słowa Enniusza, powtórzone nastẹpnie przez Cycerona (De Natura Deorum, I, XXXV). H.W. Janson, Apesand Ape Lore in the Midde Ages and the Renaissan-
Wśród malarskich i graficznych przedstawień z XVII-XVIII w. ukazujących małpy podczas picia alkoholu, palenia ty toniu, grania w gry, muzykowania, tańca itd. osobną i mniej liczną grupę stanowiły sceny z małpami w rolach malarzy i rzeźbiarzy. Małpich artystów z tego okresu znaleźć można w dorobku trzech twórców: Davida Teniersa Mł (1610-1690), Antoine' Wattea (6684-172) i Jeana Chardina (169179). Singeries trzech róznych malary 179g). Singeries trzech róznych malarzy, o odmiennym pochodzeniu, tradycji i charakterze twórczości, tączy podejmowan tych samych problemów związanych $\mathrm{z}$ działalnością artystyczną. Jednym z nich była konfrontacja z „małpią" naturą tworzenia - naśladownictwem, które zawsze, w mniejszym lub większym stopniu, jest udziałem każdego artysty.

\section{"SZTUKA MALPA NATURY"}

Twórczość oparta na naśladowaniu natury (mimesis, imitatio) znalazła analogię we wrodzonych skłonnościach małpy, naśladowcy par excellence. Powstały na tej kanwie topos ars simia naturae odnosił sie do sztuki dążącej do jak najwierniejszego obrazu rzeczywistości². U źródeł tego konceptu leżało pozytywne przeświadczenie, że nadrzędnym celem sztuki jest

A. Ziemba, Iluzja a realizm. Gra $z$ widzem w sztuce

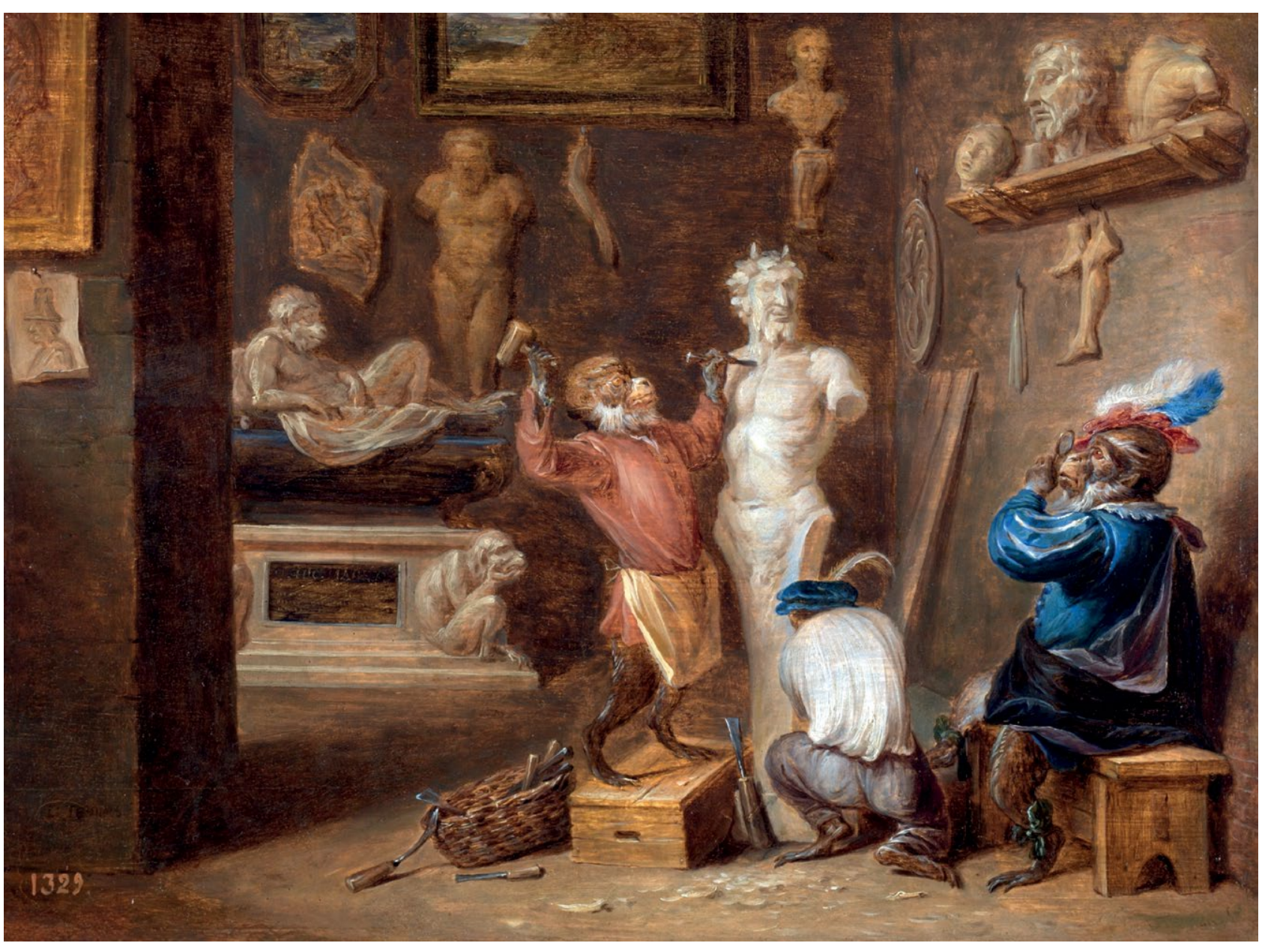

1. David Teniers Mł., Małpa rzeźbiarz, 1660 r., Madryt, Prado.

naśladownictwo natury, jednak ze względu na wszelkie negatywne konotacje małpiej symboliki, metafory z jej udziałem nabierały najczęściej pejoratywnego znaczenia. (yjczęsciej pejoratywnego znaczenia. mbol szatana (simia Dei), wizerunek grzesznika, obraz cielesnej kondycji ludz kości, zawsze oznaczała niegodnego (zwierzęcego) naśladowcę, pretendującego do miana człowieka. Epitet simia już od starożytności oznaczał oszusta i zwodziciela, ale akże kogó, kto náladuje szlachetny idear wabre pol wiąże postac małpy zelenentem kłamstwa wpisanym w sztukę iluzjonistyczną, rozpatrywaną w sensie platonskim jako mamiąca zmysły, oddalającą od sfery transcendentnej i świata prawdziwych idei. Potwierdzają

$\overline{\text { 3.W.W.Janson, Apes..., }}$ dz. cyt., s. 287 to słowa Alaina z Lille, który, mimo zachwytu nad niezwykłymi „cudami” malarstwa, jednocześnie je potepił nazywając simia veri - małpą prawdy ${ }^{4}$. Określenie "małpa" początkowo pociagało więc za sobą skojarzenia z naśladownictwem prowadzącym do iluzji, bądź zbudowanym na fałszus. Małpa w tej roli objawia się ponownie w dziele Genealogia Deorum z ok. 1360 r., włoskiego teoretyka i poety Boccaccia. Opisana przez autora jedna z historii mitologicznych mówiła o Epimeteuszu, który w ramach kary za wykonanie glinianej

W. Tatarkiewicz, Dzieje sześciu pojęć. Sztuka, pięhno, forma, twórczośs odtwórczośś prezeżycie estetyczne, forma, tworczossc, odtwi

W podobnym sensie pojecie małpa natury" pojawia się zostaje w ten sposób alchemik i fałszerz metali Capocchio. D. Arasse, Detal. Historia malarstwa u samego Dantego. W XXIX pieśni Piekła określony 


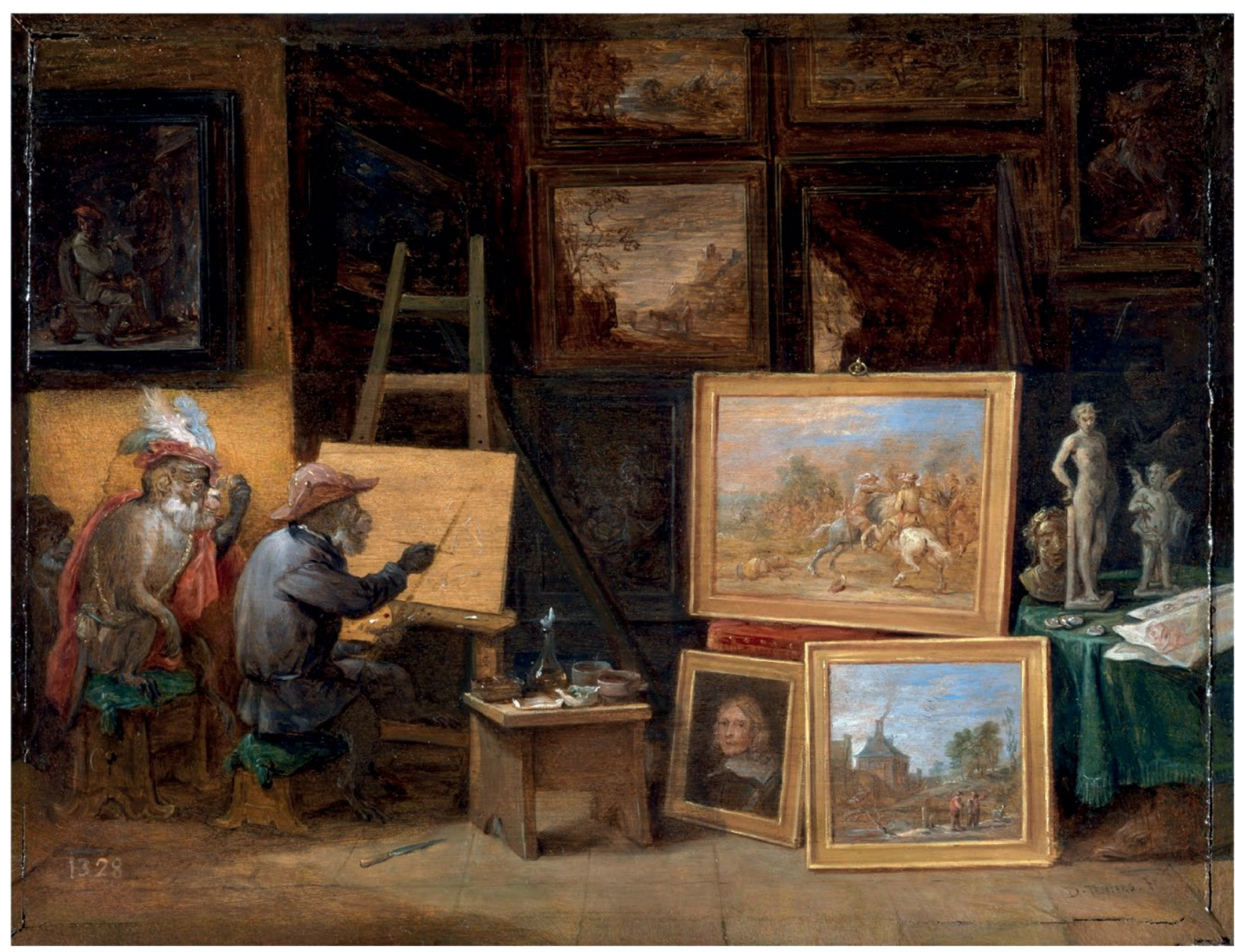

2. David Teniers Mł., Małpa malarz, 1660 r., Madryt, Prado.

Fot. domena publiczna

figurki człowieka został przez Jowisza zmieniony w małpę i zesłany na wyspe Pithecusae, znanej z tego, że zamieszkiwał je małpy ${ }^{6}$. W innym kontekście, antycypującym nowożytne spojrzenie na artystyczne naśladownictwo, zwierzę pojawia się w historii Wulkana, który wylądował wśród małp po strąceniu go z nieba. Opowieść o Wulkanie - boskim kowalu, „panu ognia” i protoplaście artystów, może stanowić metaforyczne przekazanie faktu, że czlowiek ze swoimi zdolnosciamido naże człowiek ze swoimi zdolnościami do na-

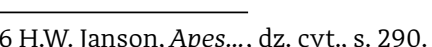

ich wykorzystać w swojej twórczości, póki nie zdobędzie ognia (uosobionego przez Wulkana)', pozwalającego tworzyć coś więcej niż epimetejskie simulacrum.

$$
\text { Począwszy od XV w. kwestia naśla- }
$$
dowania w sztuce stała się przedmiotem licznych rozważań teoretycznych i filozoficznych, co sprawiło że zaczęła nabierać coraz więcej złożonych i odmiennych znaczeń. Szczególnie istotną rolę odegrał koncept, poruszany przez wielu renesansowych i barokowych pisarzy, a wywodzący się jeszcze od Arystotelesa, głoszący, M. Poprzęcka, Kuźnia. Mit, alegoria i symbol, Warszawa że sztuka powinna naśladować naturę nie w sposób dosłowny, a poprzez zastosowanie odpowiedniego przetworzenia, co więce - ze moż ją przewyżyc 依 skonalic. W ten sposab rozproszone piękno sę w jednym miejscu -

Ten kontekst sprowadził znaczeni małpy do symbolu prostego, surowego o wzorowywania wyglądu rzeczywistości. Jako jeden $\mathrm{z}$ atrybutów Imitatio zwierzę to zostało umieszczone w Iconologii Cesarego Ripy opublikowanej w $1599 \mathrm{r}^{8}$ Imitatio zosta przedstawione jako kobieta trzymająca w jednej droni pędzle, w drugiej mack wón je cę a je stop pojawla się malpa ku stanowiła symbol dośc neutralny, o tyle wZywotach z 1672 r. Giovanniego Pietra Belloriego małpa zostaje przygnieciona stop Prudentii. W odniesieniu do teorii sztuki Belloriego, zakładającej wybór z natury, oparty na idei powstałej wcześniej w umyśle artysty ${ }^{9}$, ilustracja ta symbolizuje zwyciestwo postulatu poprawiania natury i rozum nego naśladownictwa nad bierną imitacją Jednak na pocz jia się ró mi w pozytywnej, a nawet dojawia się równieź w pozytywnej, a nawet doniosłej roli. W jednej z rycin, zamieszczony w dziele Roberta Fludda Utriusque Cosm Historia z lat 1617-1619, ukazano małpę w otoczeniu rozmaitych przedstawień dziedzin naukowych i artystycznych, wśród których znalazło się także malarstwo. Małpa ukazana w roli przewodnika po sztuce podkreśla zawartą w dziele Fludda idee że wszelka zaw wiedza i dzmię z badania i našladowania natury, tym

\section{H.W. Janson, Apes..., dz. cyt., s. 304}

9 GP. Bellori, dea malarza, rzé́biarza iarchitekta wybrana z piękna natury, [lecz] przewyższajacca nature, 1664 w: Teoretycy, historiografowie iartyści o sztuce 1600-1700, oprac. J. Białostocki, red. M. Poprzęcka, A. Ziemba, Warszawa 1994, s. 218

I I. Trzcińska, Logos, mit i ratio. Wybrane koncepcje
ORYGINALNOSC I ODTWORCZOSC

Znaczenie małpy w kontekście artystycznym zmieniało się w czasie, podobnie jak zmianie ulegały poglądy na náladownictwo isamą sztuke Jej obecnóć zaw jednak dotycyla delka jo kwestil oryszjednak dotyczyla delikatnej kwestii orygnalności i granicy między kopią a inspiracją. Do tego problemu nawiązał David Teniers Mł. - główny przedstawiciel gatunku singerie, uznawany za inicjatora przedstawień małp w rolach malarzy, rzeźbiarzy i koneserów sztuki. Małpy jako artyści pojawiają się w dwóch jego obrazach z ok. 1660 r. z Prado (Małpa rzeźbiarz, Małpa malarz, il. 1, 2).

Małpa rzeźbiarz przedstawia małpiego artyste który z wielkim zapałem wykuwa posąg satyra pod czujnym okiem zleceniodawcy lub konesera. U stóp rzeźby znajduje się pomocnik małpiego mistrza, a odlewy po fragmentach słynnych dzieł klasycznych zdobią ściany pracowni. W tle znajduje się skończone dzieło - grobowiec z półleżącą postacią, utrzymany w tradyci włoskiego renesansu. Przedstawienie nabiera wyraźne komicznego charakteru wzędu na to ze wękzosc rzezb zna ze wzgędu na to, że większosć rzeźb znajdujących się w pracowni stanowi fuzję małpy i człowieka. Podobne hybrydalne połączenia widoczne są w rycinie przedstawiającej małpią Grupę Laokoona autorstwa Niccola Boldriniego z ok. 1545 r., wykonana na podstawie rysunku Tycjana ${ }^{11}$

Począwszy od XV w. koncepcja imitatio objęta tury, ale także tych twórców, których

11 Istnieje szereg teorii na temat celu powstania ryciny: od krytyki wzorowania się na starożytnych dziełach aż po wątki dotyczące anatomii porównawczej. Najwczesniejsza mowwi o tym, ze rysunek Tycjana mia być satyra na nieporadną kopię Grupy Laokoona karykatura ta miała być próbą uwolnienia się malarz spod wpływu, jaki miała na niego starożytna rzeźba. H.W. Janson, Titian's Laocoon Caricature and the Vesalian-Galenist Controversy, ,The Art Bulletin”, vol. 


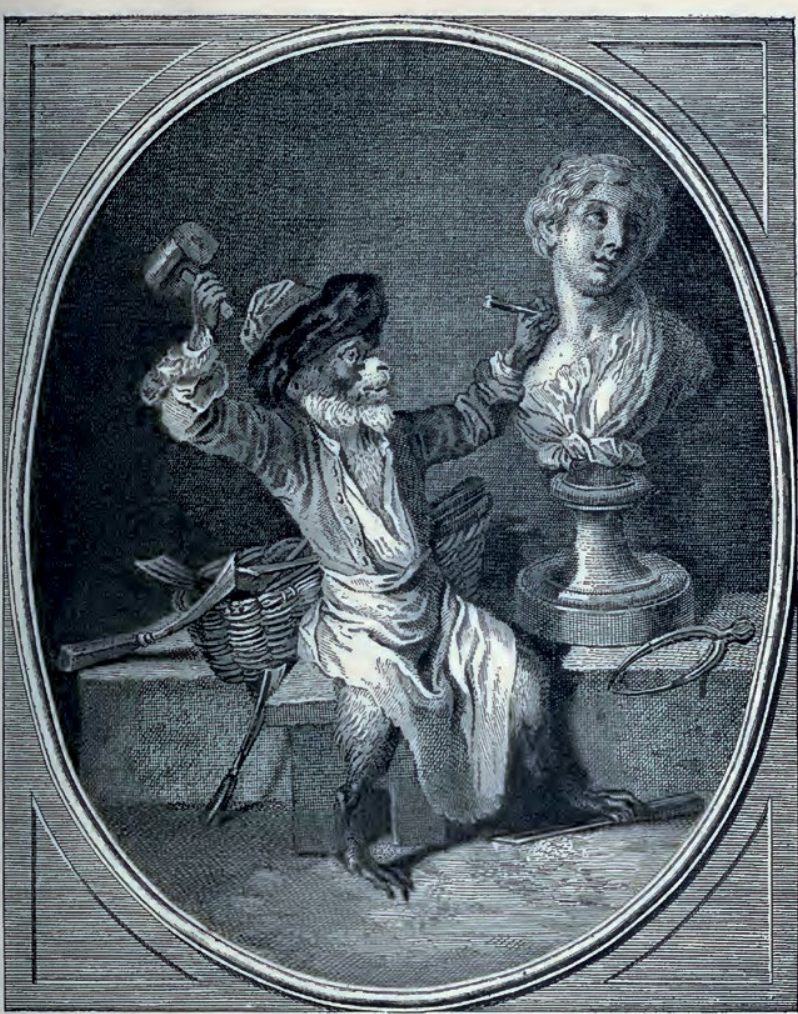

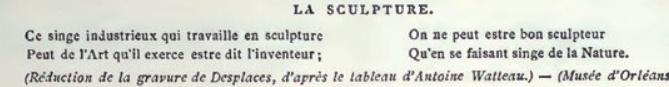

uważano za niedościgniony wzór w oddawaniu piękna natury - czyli starożytnych ${ }^{12}$ Przeciwko ślepemu kopiowaniu antycznyc wzorów występował Erazm z Rotterdamu, nazywając małpami tych uczonych, którzy zbyt wiernie odtwarzali styl Cycerona ${ }^{13}$. Małpa rzeźbiarz również może stanowić komiczną wizualizację „małpiej”, czyli koniczna wizunlizacje, mazpi odtwórczej initacji opartej na dziełach wielkich klasycznych rzeźbiarzy z przeszłości. Podobne skojarzenia odnaleźć moż na w Matpim malarzu. Przedstawiono w nim kolejnego małpiego artystę w pracowni wy-
pełnionej najróżniejszymi dziełami sztuki, wśród których odnaleźć można pejzaż,

12 W. Tatarkiewicz, dz. cyt., s. 321.

$13 \mathrm{~K}$. Gouwens, Erasmus "Apes of Cicero" and Conceptual Blending, , Journal of the History of Ideas" 2010, nr 4 ,
3. Louis Desplaces wg Antoine'a Watteau . Sculpture, ok. 1710-1730. Fot. wg Les artistes célebres, t. 1, Paris 1886, s.

portret, sceny batalistyczne, rodzajowe, a także antyczne figurki. Różnorodność ukazanych dzieł może przywodzić na myśl bezrefleksyine odtwarzanie dziet innych twórców oraz nienożnóć znalezieni wypracowania whasnego stylu. W przeciwypracowania wlasnego stylu. W przeciwienstwie do przedstawienia rzeźbiarza w Małpie malarzu akcent satyryczny połozony został na postaci fałszywego konesera, który z bezmyślnym usmiechem spogląda na płótno. Być może obraz nie odnosi się wcale do kwestii oryginalności, a przedstawia trudną pracę twórczą, ograniczoną często do życzeń zleceniodawców, a także zależną od ich pieniędzy, co podkreślone zostaje przez sakiewkę umieszczoną na pazostaje przez sakiewkę
sku małpiego konesera.

Do problemu tworzenia na wzór starożytnych nawiązywał również Antoine Watteau, w perspektywie odnoszącej się do doktryn i sposobów nauczania Królewskiej Akademii Malarstwa i Rzeźby w Paryżu. W swoim Małpim rzeźbiarzu z ok. $1710 \mathrm{r}$. znajdującym się w Musée des Beaux-Arts 'Or d Orléans, przedstawit marpiego artystę podczas twi pron sia. W rycinie Loulsa Desplaces'a - La sculp - powstałej na wzor obrazu Watteau, znajduje się komentarz, ktorego dwa ostatnie wersy głoszą (w tłumaczeniu na język polski): nie będzie dobrym rzeźbiarzem ten, kto czyni się małpa natury ${ }^{14}$ (il. 3). Jawne odniesienie do kwestii naśladowania zdaje się być dość przekorne, biorąc pod uwage fakt, że Watteau wyraźni inspirowal Wect Ten .

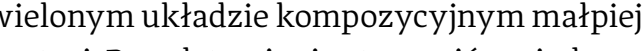
postaci.Przedstawienie stanowić może krytykę narzuconego przez paryską Akademię postulatu naśladownictwa antyku, uwazanego za podstawę dobrej sztuki's.

14 On ne peut estre bon Sculpteur/ Qu'en se faisant Singe de la Nature.

K K. Secomska, Spór o starożytność. Problemy malarstwa
4. Louis Desplaces wg Antoine'a Watteau, La Peinture, ok. 1710-1730. Fot. domena publiczna

Podobne odwołanie do zapatrzenia w starożytność w pełnej krasie zaprezentowa również Jean Chardin w Małpim antykwariuszu, wystawionym na Salonie w 1740 r., często przypisywanym Watteau'16. Małpi kolekcjoner przedstawiony w nonszalanckiej pozie, siedzi w gabinecie i z uwagą przygląda się tarożytnemu medalowi, który porównuje z innymi znajdującymi się rozłożonej przed nim książce. Rycinie Pierre’a Louisa Surugue, powstałej na wzór obrazu Chardina, towarzyszy podpis, ułożony przez CharlesaEtienne’a Pesseliera. Głosi on, w tłumaczeniu: Dlaczego, uczony czlowieku, musisz ubić się w ciemnym labiryncie starożytnych zabytków? Nasze stulecie oglądane oczami prawdziwego filozofa oferuje wy-

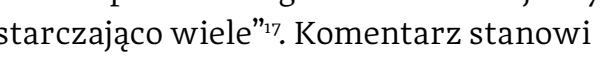
oczywiste nawiązanie do wielkiego sporu literacko-artystycznego między starożytnikami i nowożytnikami - Querelle des Ancien et des Modernes, toczącego się od końca XVII w., rozpoczetego wystapieniem Charles'a Perraulta w 1687 r. i wciąż żywego w pierwszej połowie XVIII w.18 Zarówno Watteau, jak i Chardin, krytykują zbytnie zaabsorbowanie jednym rodzajem sztuki. absorbowanie jednym rodzajem sztuki.
Kolekcjoner gromadzący jedynie klasyczn Kolekcjoner gromadzący jedynie klasyczne obiekty, zamiast popierać twórczość swoich czasów, przedstawiony został na podobieństwo małpy kopiującej starożytne popiersie. Jeszcze inny problem zasygnalizowa Watteau w pendant do Matpiego rzeźbiarzaprzedstawieniu małpiego malarza, dziele zaginionym, znanym jedynie z ryciny Louisa Desplaces'a (La peinture). Małpi artysta, choć trzyma w łapce paletę, nie rozpoczyna pracy, a odwraca wzrok od płótna w kierunku

6. Rosenberg Chardin $1699-1779$, thum. E. Kadish U. Korneitchouk, red. S.W. Goodfellow, Cleveland 1980, s. 222

17, Dans le Dédale obscur de monuments Antiques / Homme Docte, à grands frais, pourquoi t'embarrasser? / Notre siècle à deus yeux vrayment philosoK .

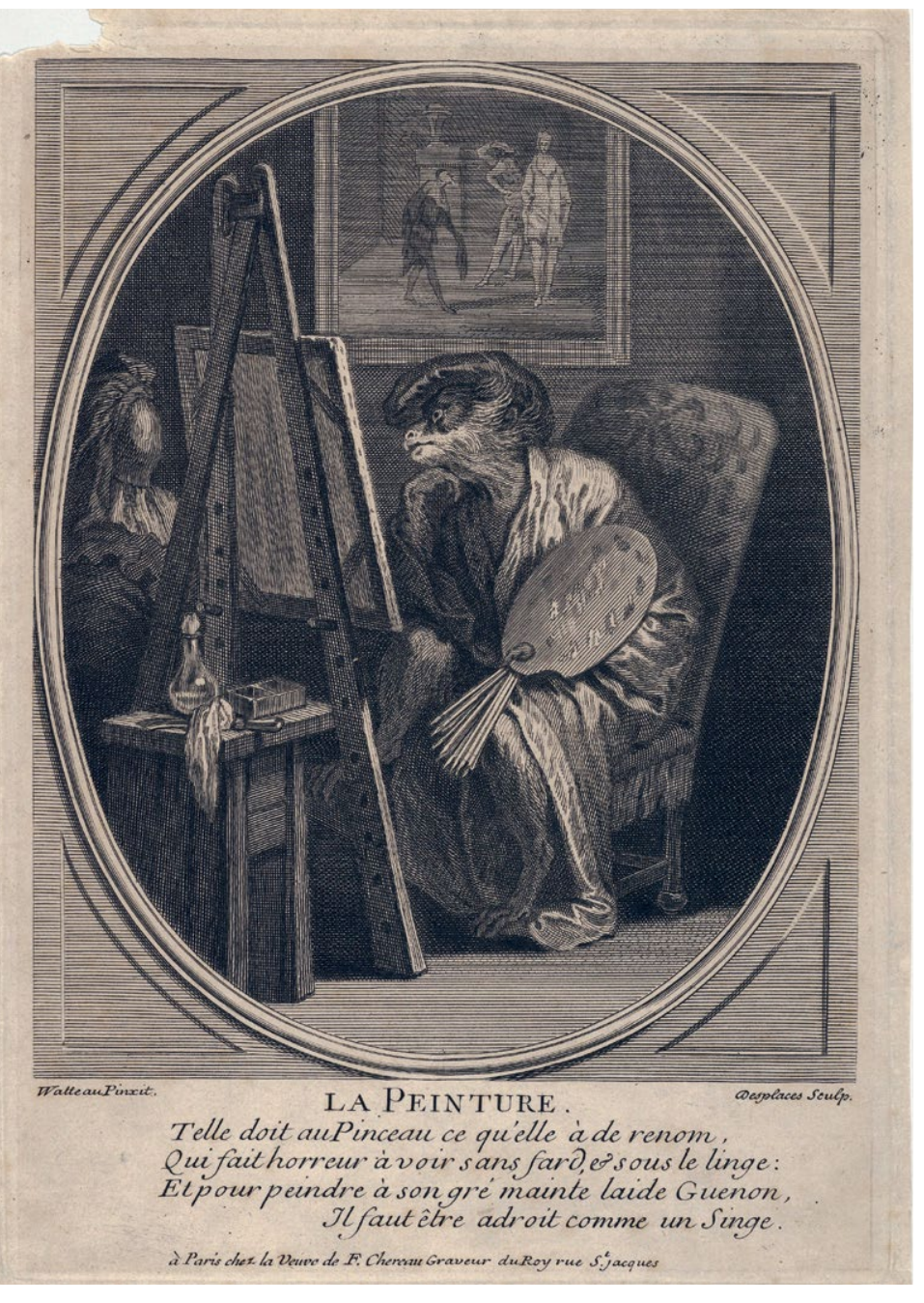

stojącego obok manekina (il. 4). Dwa ostatnie wersy towarzyszące rycinie brzmią w przekładzie: ,żeby nąe ryćc bredle uznania niejednego szpetnego koczkodana, trzeba być zręcznym niczym małpa"1 ${ }^{19}$, w dosłownej interpretacji krytykując tych, którzy swój piękny wygląd zawdzięczają jedynie pędzlowi artysty. Małpa przedstawiona zostaje w kilku rolach: symblo próz zostaje wo naśl rowcy, jaki pochlebcy Jak podaje Horst W. Janson, skojarzenia małpy ze sztuką portretową pojawiły się w drugiej połowie XVI w. wraz ze wzrostem znaczenia te lukratywnej dziedziny malarstwa ${ }^{20}$. Krytyka uderzała często w klientów, zwłaszcza w kobiety, jak prezentuje to rycina pochodząca

\section{9 „Et pour peindre à son gré mainte laide Guenon, /}

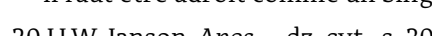


demia nobilissimae artis pictoriae oachima von Sandrarta, przedstawiająca elegancko ubraną małpią damę pozującą do portretu. Z kolei sam praktykant szt tretowej zostal postawiony w roli tresowanej małpy, chętnej do przedkładania życzeń klientów nad wierność rzeczywistemu wizeunkowi. W nawiązaniu do tej ilustracji komentarz pod ryciną Desplaces'a może być ni tyle odniesieniem do portretowanych dam, które „psuły” rynek artystyczny, domagając się idealizacji, ile do akademickiej krytyki naturalizmu i postulatu nieubłaganej korekcji niedoskonałości natury ${ }^{21}$ Modelka, czyli

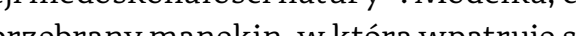
przebrany me malpiartysta, stanowiénoże rozróznienie pomiędzy rodzajem malarstwa, jaki uprawiał Watteau, a sztuką propagowaną przez Akademię, która swoją analogię znalazła w sztucznie ufryzowanej kukle.

Zamyślona małpa-malarz Watteau stanowi kontrapunkt do żywiołowego rzeźbiarza, budząc skojarzenia ze sporami pojawiajacymi się już od XV w. dotyczącymi współzawodnictwa różych sztuk. Malarstwo min. kojarzone bylo ze sztuka umysłową w przeci umysłową w przeciwienstwie do nicznej pracy rzeźbiarza, wymagającej głównie wysiłku fizycznego ${ }^{22}$. Ale małpa, biorąc pod uwagę w jakiej roli pojawia się u Belloriego, stanowi zaprzeczenie sztuki intelektualnej, co sprawia, że małpi malarz Watteau nabiera charakteru karykatury uczonej roli malarstwa akademickiego. Odmienny sposób przedstawiania ki, nie tylko u Watteau ale i u Teniersa Mt, wskazuje na nieco inne podejście twórców do własnego zawodu. Przywołuje to z kolei inną interpretację kontekst autoportretu.

21 K. Secomska, dz. cyt., s. 172-174. 2 W. Tatarkiewicz, Estetyka nowożytna, Wrocław 1967
MALPA JAKO ALTER EGO MALARZY

Dora Panofsky zwróciła uwage, że przedstawienie małpiego malarza Antoine’a Watteau może stanowić jego autoportret, o czym świadczy obraz zawieszony nad zwieo czym świadczy obraz zawieszony nad zwie zęcym artysta, z postaciani z commedia ell arte - tak chętnie podejmowanej przez stał zaczerpnięty z innego dzieła Watteau, 'honneur d'une belle, co według badaczki sugeruje wyraźny związek z artystą $a^{24}$

$$
\text { Analogiczna sytuacja występuje }
$$

w Małpie malarzu Davida Teniersa Mł Jeden zobrazów zawieszony w lewym górnym rogu pracowni przedstawia wnętrze

karczmy z siedzącą postacią, a jego kompozycja jest charakterystyczna dla

eniersowskich scen rodzajowych, ukazujących prosty lud w karczmach. Istotne jest także, że małpa dla Teniersa Mł. stanowiła motyw szczególny, co widoczne jest w samej liczbie namalowanych przez niego singeries. Małpa pojawia się również w innym jego dziele-Koncercie rodzinnym z ok. $64 \mathrm{r}$, w którym zawar Ob Obraz tenczęso interp towany jest jako podkreślenie arystokratycznego wizerunku, o który artysta bardzo dbał ${ }^{25}$. Na balustradzie tarasu, na którym malarz przedstawił siebie i swoją rodzinę podczas muzykowania, znajduje się małpa, która jako zwierzę egzotyczne mogła symbolizować zamożność artysty. Jednak według Berta Schepersa była wyrazem pragnienia pokazani siebie jako wierwszorzęd parza motywu matp whdzkich ro

23 D. Panof sky, Gilles or Pierrot? An iconographic study of Watteau, ,Gazette des beaux-arts", vol. 39, 1952, s. 334 24 Tamże. A biography, Turnhout 2011, s. 25.

26 B. Schepers, La folie des singes à Anvers au XVIIe Schepers_La_folie_des_singes_\%c3\%A0_Anvers_au_ malarza tematyki ${ }^{23}$. Układ kompozycyjny zo powtórzonego w formie ryciny-Pour garder

$25 \mathrm{H}$. Vlieghe, David Teniers the younger (1610-1690). siècle, https://www.academia.edu/36829427/Bert_

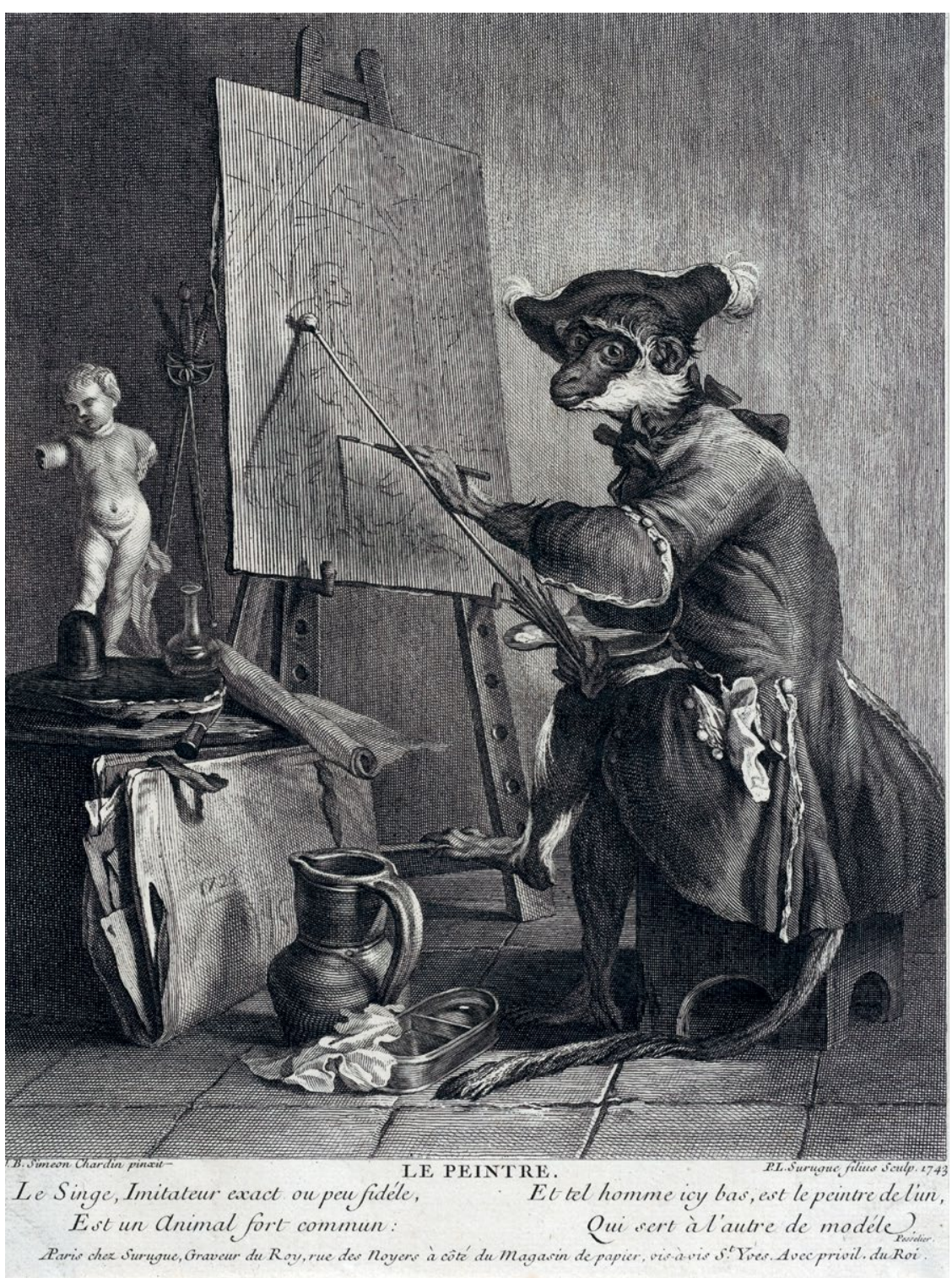

Podobną manifestację mogłoby stanowić przedstawienie małpiego malarza, ktorego tytuł w tej interpretacji brzmiałby: Malarz małp.

Mimo że małpa była synonimem złego naśladowcy, rzadko pojawia się w kontekście nieudolnej imitacji, a raczej zbyt wiernej, pozbawionej odpowiedniego przetworzenia. Mogła oznaczać szczególną zręczność i umiejętności naśladowcze; w ten sposób pozytywną waloryzację artystów jako małpy natury wyrażał np. Filippo 9publique_des_Lettres_2019_pp._153-172, s. 162
Villani ${ }^{27}$. Biorąc pod uwagę tę niejednoznaczność, artyści mogli zaprezentować się jako małpa w autoironicznym kontekście wpisanym w filozofię błazeństwa.

Małpa w roli błazna-artysty, jak podaje Simona Cohen, pojawiła się już u Vittore Carpaccia w obrazie Powrótambasadorów z ok. 1495-1496 r. z cyklu ilustracji legendy

Ĺlenie to pojawia się $\mathrm{w}$ dziele De origine civitatis Florentiae et eiusdem famosis civ poświęconemu Florenciji i jej wybitnym obywatelom.
Villani używa go w odniesieniu do malarza Stefano, chwaląc jego niezwykłą umiejętność w realistycznym oddawaniu detali ludzkiego ciała. D. Arasse, dz. cyt. 
św. Urszuli². Badaczka interpretuje zagadkową, znajdującą się poza główną narracją sceny, postać małpy w stroju błazeńskim jako autoportret samego Carpaccia, podkreślający rolę malarza jako małpy natury ${ }^{29}$. W błazeńskim i artystycznym kontekście małpa pojawia się również w biografiach malarzy Arnolda Houbrakena przy portrecie Fransa van Mierisa i Jana Steena. Umiejscowienie tego zwierzęcia z paletą w dolnym rogu obo wizerunku Steena, w nawiązaniu do temperamentu sangwinicznego, który ono symbolizowało ${ }^{30}$, obrazuje dowcipny i komediowy charakter zarówno samego artysty, jak i jego sztuki, a także znakomitą umiejętność oddawania rzeczywistości ${ }^{31}$.

Być może małpy w rolach artystów tanowią odwrócenie negatywnego symb lu na własną korzyść, jak ma to miejsce u Boccaccia przy okazji obrony poetów ${ }^{32}$ Ten prowokacyjny charakter zauważalny jest przede wszystkim u Jeana Chardina w jego Małpim malarzu (Le Singe peintre, Musée des Beaux-Arts, Chartres) wystawionym na Salonie w 1740 r. wraz

z Antykwariuszem ${ }^{33}$. Obraz Chardina przedzAntykwiuszems obraz Chardina przedstawia malpiego arystę ubranego w modny płaszcz, siedzącego przed sztalugą w in cjalnej fazie pracy nad obrazem (il. 5). Przed nim znajduje się figurka antycznego putta. Jeśli miała służyć za model, nie została przeniesiona na płótno, na którym

\section{S. Cohen, Ars simia naturae. The Animal as Mediator} and Alter Ego of the Artist in the Renaissance,

Explorations in Renaissance Culture", vol. 43, 2017, nr 2, s. 219.

30 H.W. Janson, Apes..., dz. cyt., s. 248

$31 \mathrm{H}$. Perry Ch, Apes.., dar, cyt., s. 248.

Life of Jan Steen, ,The Art Bulletin" 1993, nr 1, s. 141-142

2 W Czternastej Księdze Cenealogii autor zajuje

postaciami poetów, określonych przez krytyków

"małpami filozofów”. Boccaccio przyznaje, że poeci sa

rzeczywiście małpami, ale natury raczej, niż filozofii,

dodatkowo zalecając krytykom, żeby stali się małpa

33 P. Rosenbers, dz. cyt., s. 221-223. widoczny jest zarys małpiej sylwetki, a malarz kieruje swój wzrok ku widzowi.

$$
\text { Małpa pojawia się raz jeszcze w twór- }
$$

czóci Chardina - w Atrybutach sztuk z $1731 \mathrm{r}$.

z Musée Jacquemart-André w Paryżu ${ }^{34}$.

Dzieło przedstawia antykizujące popiersie, wokół którego znajdują się malarskie i rzeż biarskie atrybuty: młotek, paleta i pędzle oraz rolki papieru. W dolnej części oddzielonej gzymsem znalazła się małpa zajmująca się tworzeniem rysunku. Jej wzrok biegnie w kierunku marmurowej płaskorzeźby, przedstawiającej ośmioro dzieci bawiących sę z kozłem, nawiązującej do dzieba François Du zoz Duguese mą jako obraz prożności artysty próbujągo konkurowac z naturą, ale zwierzę wy aźnie odtwarza płaskorzeźbę, która zdaje się być kluczem do interpretacji umieszczenia w obrazie małpiego rysownika.

Przedstawienie płaskorzeźby z motywem dzieci i kozła stało się niezwykle popularne w XVII i XVIII w. i było wielokrotnie kopiowane i włączane do różnorodnych scen. Tradycyinie jej jbecnóc w moln scen. Tią ic e le także w treści, która odnosi się do kwes mitacji. Maska, trzymana przez ukazane lewej strony putto, symbolizuje oszustwo, zdolność łudzenia oka, które testowane jest na koźle, na podobienstwo historii Zeuksisa, który zdołał oszukać ptaki iluzją realności namalowanych przez siebie winogron ${ }^{38}$. Nawiązanie do klasycznej historii może stanowić również sukno, przysłaniające z prajić row nezs suknoj prystaniaje zrawej strony pack ca motyw płaskorzeźby dopełnia sens iluzjonistycznej władzy malarstwa,

\section{Tamże, s. 92-93.}

W. Liedke, Dutch Paintings in The Metropolitan

8 Tamże. pozwalającego na płaskiej powierzchn przedstawić złudzenie realności

i trójwymiarowości.

Charles Nicolas Cochin, opisując karier artystyczną Chardina, twierdził, że punktem wyjścia dla ukształtowania jego wizji artystycznej był królik ${ }^{39}$. Żeby oddać go tak, jak powinien, Chardin musiał „zapomnieć o tym, co widział wcześniej i o tym, jak podobne obiekty traktowali inni twórcy $y^{40 "}$. Chardin nie miał zamiaru odtwarzać każdego pojedynczego włoska na ciele zwierzęcia, ale skoncentrował się na wrażeniach optycznych, tworząc iluzię re-

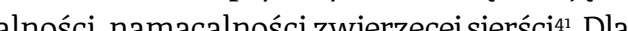
niego malarskie studium poprzedzone wnikliw obserwacją modela było istotniejsze niż wzniosł aspiracje malarstwastorii. Wyjątkowość sztuki Chardina, mimo że przedkładał martwe natury isceny rodzajowe nad malarstwo historyczne, zapewniła mu uznanie w środowisku artystycznym, ze szczególnym poparciem i niemałym zachwytem Denisa Diderota. Według filozofa sztuka miała naśladować naturę nie tyle piękną, co prawdziwą, itę odnalazł wdzietach Chardina, chwącje swej palecie, ale samą

Relacja między sztuką a naturą, któr wypracował Chardin, daleka była od nai nego odtwarzania, jakie mógł zganić w swoim Matpim malarzu. W oczywisty sposób występuje tu krytyka artystów, którzy nie są w stanie pozbyć się swojej małpiej natury, wychodzacej na jaw w ich pracach. Wydźwięk dzieła ulega jednak pewnej zmianie, gdy weźmie się pod uwagę pewnej zmianie, gdy weźnie się pod uwage

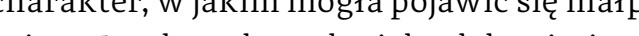
$w$ jego Atrybutach sztuk - jako dobry imitator i symbol naśladownictwa podpartego 39 S.R. Cohen, Chardin's Fur. Painting, Materialism, and
the Question of Animal Soul, „Eighteenth-Century
Studies" vol 38,2004, r

Studies, , vol. 38, 2004, in 1

40 P. Rosenberg,
41 Tamże, s. 143.

42 D. Diderot, Esej o malarstwie, ttum. J. Stadnick,

Warszawa 2015, s. 26, przypis 25. studium z natury. Zwierzęcy malarz ignorując posążek tworzy portret lub raczej aubie, nawołując do zapomnienia

szablonowego modela, a sięgnięcia do własnego wnętrza. Małpi malarz jako przekorny autoportret Chardina stanowi polemike nie tylko z wpływami innych, ale i z własną twórczością. Przedstawia sylwetkę artysty w postaci naśladowcy rzeczywistości, innymi słowy - malarza jako małpy.

***

Między trzema twórcami: Davidem eniersem Mł, Antoinem Watteau i Jeanem Chardinem, zauważalna jest nić artystycznego porozumienia. Ich singeries występują przeciw koncepcji tworzenia rozumianej jako powielanie dawnych wzorów, zadając pytania o oryginalność, kreatywność i artystyczną tożsamość - problemy, z którymi na swojej drodze zmaga się każdy twórca. Małpa staje się nośnikiem tych treści. Tak rozumialjäjörg Immendorf wspól. Tak

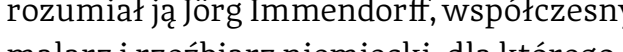
malarz i rzeźbiarz niemiecki, dla którego
zwierzę stało się artystycznym alter ego: „Dla zwierzę stało się artystycznym alter
mnie małpa była po prostu drugim Ja. Symbolem ambiwalencji artystycznej egzystencji, pewności i zwątpienia w samego siebie. Jest zarazem nieporadna i mądra, to symbol przeciwieństw ${ }^{43}$.

Artykut powstał na podstawie pracy magisterskiej napisanej w 2020 r. w Instytucie Historii Sztuki UKSW pod kierunkiem dr hab. Anny Sylwii Czyż, prof. ucz. M. Skłodowska, Wschody i zachody malarstwa, „Art 


\section{STRESZCZENIE}

DEA TWORCZOSCII FIGURA ARTYSTY W SINGERIES DAVIDA TENIERSA

MLODSZEGO, ANTOINE'A WATTEAU

I JEANA CHARDINA

Niniejszy artykuł prezentuje problematykę artystycznego naśladownictwa na przykładzie przedstawień małp jako malarzy, rzeźbiarzy i koneserów sztuki, autorstwa Davida Teniersa Mł., Antoine’a Watteau i Jeana Chardina. Sceny te należały do gatunku satyrycznych przedstawień funkcjonujących w języku francuskim pod nazwą singerie, ukazujacych malpypodczas parcing wrazujacych przeróżych ludzkich zynnosci. Niekwestion wanym nistrzengatunku stal się flamandzki malarz David Teniers Mł., który spopularyzował temat małp w rolach artystów, a za nim, prawie stulecie później, podążyli Antoine Watteau i Jean Chardin Skłonności naśladowcze, przypisywane małpie od starożytności, zaowocowały skojarzeniem zwierzęcia z mimetyczną rolą sztuki, a dosłownym wyrazem tejanalogi staka się meta stala sie metafora ars simianaturae (szt two tworców nie tylko nawiązją do toposu naśladowania rzeczywistości, ale i przewrotnie go przekształcają w charakterystyczny dla tego tematu, ironiczny sposób. Małpa uwikłana zostaje w toczące się od czasow renesansu spory teoretyczno-artystyczne, których omawiane przedstawienia stanowią niejako kontynuację. Za pośrednictwem zwierzęcia artyści dotykają problemu imitatio i inventio, co w przypadku Watteau

i Chardina przyjęło formę sprzeciwu wobec tendencji akademickich. Te, na pozór jedynie zabawne przedstawienia, niosą ze sobą znaczenie o wiele poważniejsze - poruszają kwestie oryginalności i artystycznej tożsamości. Podobnie jak sztuka „małpowała” naturę, tak dla malarzy małpa stała się ich alter ego, dlatego w artykule zaznaczony został także kontekst autoportretu.

\section{SUMMARY}

DEA OF CREATIVITY AND THE FIGURE OF THE ARTIST IN SINGERIES BY DAVID TENIERS THE YOUNGER, ANTOINE WATTEAU AND JEAN CHARDIN

This article presents the issue of artistic imitation on the example of monkeys that are depicted as painters, sculptors and art connoisseurs by David Teniers the Younger, Antoine Watteau and Jean Chardin. These scenes were a part of a visual art genre called singerie. The name has been given from French word singe - monkey, ape Although the practise dates back to medieval drôlerie, their greatest populanity in European art fill in the 17 hand 18 th century. The depictions of monkeys imitating human behaviours were a perfect parody of human nature, not only in a moral way, but also in connection with creativeness. The Flemish painter David Teniers the Younger popularised the subject of the artist as an ape. This tradition was subsequently adopted by Antoine Watteau and Jean

Chardin in France. The monkey was an imches importantsymol of initation. In result, this the aning of an animal was associated with me art initating reality and the expression of this analogy was the metaphor ars simia naturae (art is an ape of nature). The singeries of the mentioned artists refer to the topos of imitating nature and have strong historical significance that continues the aesthetics discussions about the mimetic role of art. These, apparently funny depictions, carry much more serious meaning - emphasize the The " became an alter ego of the painters.

\section{SŁOWA KLUCZOWE}

David Teniers Młodszy, Antoine Watteau, Jean-Baptiste Siméon Chardin, singerie, ars simia naturae, autoportret

\section{BIBLIOGRAFIA}

Arasse D., Detal. Historia malarstwa w zbliże niu, tłum. A. Arno, Kraków 2013 ellori G.P. Idea malarza, rzeźbiarza i architekta wybrana z piękna natury, [lecz] przewyższająca naturę, 1664, w: Teoretycy, historiografowie i artyści o sztuce 1600-1700, oprac. J. Białostocki, red. M. Poprzęcka, A. Ziemba, Warszawa 1994, s. 218-233

Chapman H.P., Persona and Myth in Houbraken's Life of Jan Steen, „The Art Bulletin" 1993, nr 1, s. 135-150.

Cohen S., Ars simia naturae. The Animal as Mediator and Alter Ego of the Artist in the Renaissance, „Explorations in Renaissance Culture", vol. 43, 2017, nr 2, s. 202-231.

Cohen S.R., Chardin's Fur. Painting, Materialism, and the Question of Animal Soul, „Eighteenth-Century Studies", vol. 38, 2004, nr 1, s. 39-61.

Diderot D., Esej o malarstwie, tłum. J. Stadnicki, Warszawa 2015.

Gouwens K.. Erasmus "Apes of Cicero" and Conceptual Blending, "Journal of the History of Ideas" 2010, nr 4 s. 523-545.

anson H.W., Apes and ape lore in the Middle Ages and the Renaissance, Londo 1952

Janson H.W., Titian's Laocoon Caricature and the Vesalian-Galenist Controversy, „The Art Bulletin", vol. 28, 1946, nr 1, s. $49-53$

\section{KEYWORDS}

David Teniers the Younger, Antoine Watteau, Jean-Baptiste Siméon Chardin, singerie, ars simia naturae, self-portrait

Liedtke W., Dutch Paintings in The York 2007. graphic study of Watteau, , Gazette des beaux-arts”, t. 39, 1952, s. 319-340.

Poprzęcka M., Kuźnia. Mit, alegoria i symbol, Warszawa 1972.

Rosenberg P., Chardin 1699-1779, tłum. .P. Kadish, U. Korneitchouk, red. S.W. Goodfellow, Cleveland 1980.

Schepers B., La folie des singes à Anvers au

XVIIe siècle, https://www.academia. edu/36829427/Bert_Schepers_La folie_des_singes_\% $C_{3} \%$ Ao_Anvers_au XVIII_si\%C_\%A8cle_Les

Collections_de_la_R\%C $3 \%$ Agpublique_des_Lettres_2019_pp._153-172 [dostęp 16 III 2020].

Secomska K., Spór o starożytność. Problemy malarstwa w „Paralelach” Perrault, Warszawa 1991.

Skłodowska M., Wschody i zachody malarstwa, „Art \& Business”, t. 20, 2008, s. nlb.

Tatarkiewicz W., Estetyka nowożytna, Wrocław 1967.

Tatarkiewicz W., Dzieje sześciu pojeć. Sztuka piękno, forma, twórczość, odtwórczość, przeżycie estetyczne, Warszawa 1976. Trzcińska I., Logos, mit i ratio. Wybrane koncepcje racjonalności od XV do XVII wieku, Kraków 2011.

Vlieghe H., David Teniers the Younger (16101690). A Biography, Turnhout 2011.

Ziemba A., Iluzja a realizm. Gra z widzem w sztuce holenderskiej 1580-1660, Warszawa 2005. 